
FIT(PATOLOGI
Volume 9, Nomor 5, Oktober 2013
IN DONESIA
Halaman 153-159
ISSN: $2339-2479$
DOI: $10.14692 / j f i .9 .5 .153$

\title{
Khamir Antagonis untuk Pengendalian Penyakit Antraknosa pada Buah Avokad Selama Penyimpanan
}

\section{The Use of Antagonistic Yeast for Controlling Anthracnose Disease on Avocado Fruit During Storage}

\author{
Yuli Fitriati $^{1,2}$, Suryo Wiyono ${ }^{{ }^{*}}$, Ivone Oley Sumarauw ${ }^{1}$ \\ ${ }^{1}$ Institut Pertanian Bogor, Bogor 16680 \\ ${ }^{2}$ Badan Karantina Pertanian, Jakarta 12550
}

\begin{abstract}
ABSTRAK
Antraknosa yang disebabkan oleh Colletotrichum gloeosporioides merupakan penyakit penting pada buah avokad dalam penyimpanan. Metode pengendalian yang efektif, murah, dan aman diperlukan untuk menggantikan fungisida dalam pengendalian penyakit pascapanen. Penelitian ini bertujuan mendapatkan dan mengidentifikasi khamir antagonis dari avokad yang efektif mengendalikan penyakit antraknosa pada buah avokad. Penelitian dimulai dengan isolasi $C$. gloeosporioides dan khamir dari buah avokad, diikuti dengan uji in vivo, uji antibiosis, dan uji aktivitas kitinolitik. Uji in vivo dilakukan dengan pencelupan buah avokad dalam suspensi sel khamir. Khamir yang berhasil diisolasi dari buah avokad ialah sebanyak 23 isolat. Berdasarkan uji in vivo, terdapat delapan isolat khamir yang efektif menghambat penyakit antraknosa pada buah avokad pada konsentrasi $10^{6} \mathrm{~mL}^{-1}$ dan $10^{7} \mathrm{~mL}^{-1}$. Namun hanya empat isolat yang dipilih untuk identifikasi berdasarkan morfologi dan molekuler. Dua spesies khamir yang diidentifikasi ialah Pichia anomala (isolat A33 dan A37) dan Candida intermedia (isolat A35 dan A36).
\end{abstract}

Kata kunci: Candida intermedia, Colletrotichum gloeosporioides, penyakit pascapanen, Pichia anomala

\begin{abstract}
Anthracnose caused by Colletotrichum gloeosporioides is an important disease in avocado fruit during storage. An effective, cheap, and safe control method is necessary as an alternative to subtitute the use of fungicides in postharvest disease control. This research aimed to identify yeast antagonist from avocados that are effective in controlling anthracnose disease on avocado fruit. Research was started with isolation of $C$. gloeosporioides and yeast from avocado fruit, followed by in vivo bioassay, antibiosis assay, and chitinolitic activity assay. In vivo bioassay was done by dipping avocado fruit on yeast cell suspension. As many as 23 yeasts isolates was obtained from avocado fruits. Eight yeast isolates (A28, A32, A33, A34, A35, A36, A37, A38) showed very effective for inhibiting anthracnose disease in avocado fruit at concentration of $10^{6} \mathrm{~mL}^{-1}$ and $10^{7} \mathrm{~mL}^{-1}$. However, only four isolates were chosen for further characterization based on morphological and molecular identification. Two species of yeast was identified as Pichia anomala, i.e. isolates A33 and A37 and Candida intermedia, i.e. isolates A35 and A36.
\end{abstract}

Key words: Candida intermedia, Colletrotichum gloeosporioides, Pichia anomala, postharvest disease

*Alamat penulis korespondensi: Departemen Proteksi Tanaman, Fakultas Pertanian, Institut Pertanian Bogor, Kampus Darmaga, Jalan Kamper, Bogor 16680

Tel: 0251-8629364, Faks: 0251-8629362, Surel: swiyono2@yahoo.de 


\section{PENDAHULUAN}

Avokad (Persea americana) merupakan salah satu produk hortikultura yang bernilai ekonomi tinggi dan merupakan komoditas target ekspor. Busuk buah pascapanen yang disebabkan Colletotrichum gloeosporioides merupakan masalah utama pada buah avokad karena cendawan ini menyebabkan penyakit antraknosa yang bersifat laten. Gejala berupa bercak berwarna cokelat akan muncul pada saat buah menjadi lembut sehingga buah tidak dapat dipasarkan.

Saat ini terdapat kecenderungan global untuk mengurangi penggunaan fungisida dan mencari alternatif pengendalian penyakit pascapanen yang lebih aman dan ramah lingkungan, misalnya dengan menggunakan agens hayati. Beberapa mikrob antagonis sebagai agens hayati telah dilaporkan dapat mengendalikan beberapa patogen pada sayuran dan buahbuahan. Khamir merupakan mikrob potensial untuk digunakan sebagai agens hayati karena mudah diperbanyak dan memiliki beberapa sifat yang dapat dimanipulasi untuk meningkatkan efisiensi penggunaannya. Beberapa tahun terakhir, khamir telah digunakan sebagai agens hayati untuk mengendalikan penyakitpenyakit pascapanen. Perlakuan khamir Pichia anomala, P. guilliermondii, Lipomyces tetrasporus, dan Metschnikowia lunata pada buah jambu dapat menekan busuk buah yang disebabkan Botryodiplodia theobromae (Hashem dan Alamri 2009). Khamir Aureobasidium pullulans dan Rhodotorula mucilaginosa yang diisolasi dari buah pir dapat menekan infeksi Penicillium expansum dan mengurangi insidensi penyakit hingga 33\% (Robiglio et al. 2011).

Eksplorasi khamir dari buah avokad dilakukan untuk mengidentifikasi jenis-jenis khamir antagonis yang efektif sebagai agens hayati yang dapat mengendalikan penyakit antraknosa pada buah avokad.

\section{BAHAN DAN METODE}

\section{Isolasi $C$. gloeosporioides dan khamir dari Buah Avokad}

Isolasi C. gloeosporioides dilakukan dengan teknik penanaman jaringan buah avokad yang bergejala antraknosa pada medium green bean agar (GBA) dan potato dextrose agar (PDA).

Khamir diisolasi dari 3 buah avokad dengan metode pencucian dan pengayaan pada medium yeast glucose chloramphenicol (YGC). Metode pengayaan dilakukan dengan cara mengambil bagian buah avokad yang telah matang sebanyak $10 \mathrm{~g}$, dimasukkan dalam $90 \mathrm{~mL}$ medium YGC dan dikocok dengan kecepatan 140 rpm selama 72 jam. Sebanyak 1 mL endapan sel khamir dipindahkan ke dalam $9 \mathrm{~mL}$ air steril dan diencerkan berseri pada $10^{-1}, 10^{-2}, 10^{-3}, 10^{-4}$, dan $10^{-5}$ untuk mengisolasi khamir pada medium agar-agar YGC dan diinkubasi selama 48 jam. Semua jenis khamir dengan morfologi berbeda diisolasi dan diremajakan pada medium PDA miring dan selanjutnya digunakan sebagai biakan koleksi.

\section{Uji Khamir pada Insidensi Penyakit Antraknosa}

Masing-masing isolat khamir disuspensikan pada konsentrasi $10^{6}-10^{7} \mathrm{sel} \mathrm{mL}^{-1}$ dengan ditambah Twin $20 \quad 0.1 \%$. Suspensi ini digunakan sebagai agens pengendalian penyakit antraknosa pada avokad. Buah avokad disterilkan dengan natrium hipoklorit 1\% selama 2 menit, dicuci 2 kali dengan air suling steril, dan dikeringanginkan. Buah avokad dicelupkan dalam suspensi khamir. Inokulasi cendawan C. gloeosporioides dilakukan dengan meneteskan $30 \mu \mathrm{L}$ suspensi C. gloeosporioides (konsentrasi $10^{7} \mathrm{~mL}^{-1}$ ) pada bagian ujung, tengah, dan pangkal buah avokad. Larutan fungisida benomil $0.5 \%$ digunakan sebagai pembanding.

Seluruh perlakuan diulang 3 kali. Insidensi penyakit diamati dan dihitung setiap hari 
selama 7 hari pengamatan dengan rumus sebagai berikut:

$$
\mathrm{KP}=\frac{\mathrm{n}}{\mathrm{N}} \times 100 \% \text {, dengan }
$$

$\mathrm{KP}$, insidensi penyakit; $\mathrm{n}$, jumlah titik inokulasi yang menunjukkan gejala sakit; $\mathrm{N}$, jumlah titik inokulasi yang diamati.

\section{Uji Antibiosis dan Uji Kitinolitik in Vitro} Khamir terhadap C. gloeosporioides

Sebanyak 1 lup khamir digoreskan pada medium PDA tepat di tengah cawan petri (Ø $9 \mathrm{~mm}$ ) secara transversal. Biakan murni C. gloeosporioides berumur 14 hari (Ø $5 \mathrm{~mm})$ diletakkan pada sisi kanan dan kiri goresan khamir dengan jarak $\pm 3 \mathrm{~cm}$, kemudian diinkubasikan pada suhu kamar. Pengamatan uji antibiosis ini dilakukan dengan mengukur lebar zona hambat khamir terhadap C. gloeosporioides setiap hari sampai hari ke15 inkubasi.

Sebanyak 1 lup khamir, umur 3 hari, digoreskan pada medium agar-agar kitin $0.2 \%$ secara transversal tepat di tengah cawan (Ø $9 \mathrm{~mm}$ ) dan diinkubasikan pada suhu ruang. Pengamatan uji kitinolitik ini dilakukan setiap hari selama 7 hari terhadap zona bening yang terbentuk pada tepi koloni khamir.

Uji antibiosis dan kitinolitik di atas disusun dalam rancangan acak lengkap dengan 5 ulangan. Data yang diperoleh dianalisis dengan Minitab 16 untuk windows. Pengaruh perlakuan dianalisis dengan sidik ragam dan apabila terdapat beda nyata dilanjutkan dengan uji beda nyata terkecil (Fisher's test) pada tingkat kepercayaan $95 \%$.

\section{Identifikasi Khamir}

Isolat khamir terpilih diidentifikasi secara morfologi dan molekuler dengan polymerase chain reaction (PCR) menggunakan primer umum $18 \mathrm{~S}$ rDNA dengan forward primer ITS1 (5'-TCC GTA GGT GAA CCT GCG G-3') dan reverse primer ITS4 (5'-TCC TCC GCT TAT TGA TAT GC-3').

Sebanyak $1 \mathrm{~mL}$ biakan khamir pada medium potato dextrose broth (PDB) disentrifugasi dengan kecepatan $15000 \mathrm{x}$ g selama 5 menit, kemudian ditambah $200 \mu \mathrm{L}$ bufer Harju dan dikocok kuat selama 1 menit. Tabung didinginkan dalam es selama 2 menit, diinkubasi pada suhu $95{ }^{\circ} \mathrm{C}$ selama 1 menit, dan didinginkan kembali dalam es selama 2 menit, dan dikocok kuat selama 30 detik. Selanjutnya, sebanyak $200 \mu \mathrm{L}$ kloroform ditambahkan, lalu dikocok kuat selama 2 menit dan disentrifugasi dengan kecepatan $15000 \mathrm{x} \mathrm{g}$ selama 5 menit. Supernatan ditambahi $400 \mu \mathrm{L}$ etanol dingin, diinkubasi dalam suhu $-20{ }^{\circ} \mathrm{C}$ selama 30 menit dan disentrifugasi pada kecepatan 15000 x g selama 8 menit. Pelet kemudian diambil dan ditambah dengan $500 \mu \mathrm{L}$ etanol dingin, disentrifugasi dengan kecepatan 15000 x g selama 8 menit. Pelet yang terdiri atas DNA khamir disuspensikan dalam $30 \mu \mathrm{L} \mathrm{ddH}_{2} \mathrm{O}$ (nuclease free water).

Sebanyak $2 \mu$ L suspensi DNA diamplifikasi dengan volume reaksi $25 \mu \mathrm{L}$ yang terdiri atas $12.5 \mu \mathrm{L}$ master mix (Qiagen), $1 \mu \mathrm{L}$ Primer Forward (ITS1), $1 \mu \mathrm{L}$ Primer Reverse (ITS4), dan $8.5 \mu \mathrm{Ll} \mathrm{dH}_{2} \mathrm{O}$. Amplifikasi menggunakan primer 18S rDNA, yaitu pasangan ITS1/ITS4. Amplifikasi dilakukan dengan mesin PCR Fast Thermal Cycler Gene Amp PCR System 9800 (PE Applied Biosystems, Norwalk US) dengan siklus denaturasi awal $95{ }^{\circ} \mathrm{C}$ selama 5 menit, denaturasi $95{ }^{\circ} \mathrm{C}$ selama 45 detik, penempelan primer $55^{\circ} \mathrm{C}$ selama 30 detik, dan ekstensi $72^{\circ} \mathrm{C}$ selama 1 menit 30 detik. Langkah ke-2 sampai dengan 4 diulang sebanyak 35 siklus dan ekstensi akhir $72{ }^{\circ} \mathrm{C}$ selama 7 menit. Elektroforesis dilakukan dalam $1.5 \% \mathrm{~b} / \mathrm{v}$ gel agarosa (TopVision, Frementas) dengan marker GeneRuler 50 bp DNA Ladder (Fermentas) dan diwarnai dengan etidium bromida.

Fragmen DNA hasil amplifikasi dikirim ke PT Genetica Science untuk sikuensing menggunakan pasangan primer ITS1/ITS4. Analisis homologi asam amino gen khamir menggunakan blast local alignment search tool (BLAST) pada situs National Center for Biotechnology Information (NCBI) (www. blast.ncbi.nlm.nih.gov). 


\section{HASIL}

\section{Colletotrichum gloeosporioides dan Khamir dari Buah Avokad}

Isolat $C$. gloeosporioides dari buah avokad yang bergejala antraknosa pada medium PDA memiliki ciri morfologi miselium berwarna putih hingga putih keabu-abuan, massa konidium kebasah-basahan berwarna seperti warna ikan salmon. Melalui pengamatan mikroskopi dapat diamati konidium membulat, hialin, bersel satu, konidiofor tegak dan memiliki seta pendek

Sebanyak 23 isolat khamir diperoleh dari 3 buah avokad dengan morfologi koloni yang beragam. Perbedaan dapat terlihat dari bentuk tepi koloni (halus atau bergelombang), elevasi koloni (datar atau cembung), bentuk sel (berantai, oval atau bulat), warna koloni (krem atau putih), dan permukaan koloni (kasar atau licin) (Tabel 1).

\section{Khamir Antagonis untuk Pengendalian Penyakit Antraknosa pada Buah Avokad}

Sebanyak 14 isolat khamir konsentrasi $10^{6}$ sel $\mathrm{mL}^{-1}$ dan 11 isolat pada konsentrasi $10^{7}$ sel $\mathrm{mL}^{-1}$ efektif dalam mengurangi insidensi penyakit antraknosa pada buah avokad yang diinokulasi C. gloeosporioides dan berbeda nyata dengan buah yang tidak diberi perlakuan dengan khamir (Tabel 2). Terdapat 13 isolat khamir pada konsentrasi $10^{6}$ sel $\mathrm{mL}^{-1}$ yang memiliki tingkat hambatan relatif(THR) sama dengan fungisida benomil. Pada konsentrasi sel khamir $10^{7} \mathrm{~mL}^{-1}$, terdapat 11 isolat khamir yang memiliki THR sama dengan fungisida (Tabel 3).

Pada penelitian ini diperoleh 8 isolat khamir yang efektif dalam menekan insidensi penyakit antraknosa pada buah avokad dan memberikan tingkat hambatan relatif yang sama dengan fungisida benomil serta berpotensi digunakan sebagai agens pengendali hayati

Tabel 1 Morfologi koloni dan bentuk sel khamir pada medium potato dextrose agar

\begin{tabular}{llllll}
\hline Biakan & Bentuk Tepi & Elevasi & Bentuk & Warna & Permukaan \\
Khamir & Koloni & Koloni & Sel & Koloni & Koloni \\
\hline A32 & Bergelombang & Datar & Berantai, oval & Krem & Kasar \\
A33 & Halus & Cembung & Bulat & Putih & Licin \\
A34 & Bergelombang & Datar & Berantai, oval & Krem & Kasar \\
A37 & Halus & Cembung & Bulat & Putih & Licin \\
\hline
\end{tabular}

Tabel 2 Kejadian penyakit antraknosa pada buah avokad yang diberi perlakuan khamir pada 7 hari setelah inokulasi

\begin{tabular}{|c|c|c|c|c|c|}
\hline \multirow{2}{*}{$\begin{array}{l}\text { Isolat } \\
\text { khamir }\end{array}$} & \multicolumn{2}{|c|}{ Insidensi penyakit antraknosa* (\%) } & \multirow{2}{*}{$\begin{array}{l}\text { Isolat } \\
\text { khamir }\end{array}$} & \multicolumn{2}{|c|}{ Insidensi penyakit antraknosa* $(\%)$} \\
\hline & $10^{6} \mathrm{~mL}^{-1}$ & $10^{7} \mathrm{~mL}^{-1}$ & & $10^{6} \mathrm{~mL}^{-1}$ & $10^{7} \mathrm{~mL}^{-1}$ \\
\hline A11 & $100.00 \mathrm{a}$ & $100.00 \mathrm{a}$ & A26 & $11.00 \mathrm{~d}$ & $89.00 \mathrm{ab}$ \\
\hline A12 & $100.00 \mathrm{a}$ & $100.00 \mathrm{a}$ & A27 & $44.33 \mathrm{bcd}$ & $33.33 \mathrm{~cd}$ \\
\hline A13 & $100.00 \mathrm{a}$ & $100.00 \mathrm{a}$ & A28 & $22.33 \mathrm{~cd}$ & $22.33 \mathrm{~cd}$ \\
\hline A14 & $100.00 \mathrm{a}$ & $100.00 \mathrm{a}$ & A 31 & $44.33 \mathrm{bcd}$ & $66.67 \mathrm{abc}$ \\
\hline A15 & $100.00 \mathrm{a}$ & $100.00 \mathrm{a}$ & A 32 & $0.00 \mathrm{~d}$ & $33.33 \mathrm{~cd}$ \\
\hline A16 & $100.00 \mathrm{a}$ & $89.00 \mathrm{ab}$ & A33 & $0.00 \mathrm{~d}$ & $0.00 \mathrm{~d}$ \\
\hline A17 & $100.00 \mathrm{a}$ & $100.00 \mathrm{a}$ & A34 & $11.00 \mathrm{~d}$ & $0.00 \mathrm{~d}$ \\
\hline A 21 & $89.00 \mathrm{ab}$ & $89.00 \mathrm{ab}$ & A 35 & $33.33 \mathrm{~cd}$ & $0.00 \mathrm{~d}$ \\
\hline $\mathrm{A} 22$ & $33.33 \mathrm{~cd}$ & $55.33 \mathrm{abc}$ & A36 & $33.33 \mathrm{~cd}$ & $0.00 \mathrm{~d}$ \\
\hline A 23 & $22.33 \mathrm{~cd}$ & $43.33 \mathrm{bcd}$ & A37 & $22.33 \mathrm{~cd}$ & $0.00 \mathrm{~d}$ \\
\hline A24 & $78.00 \mathrm{abc}$ & $22.00 \mathrm{~cd}$ & A38 & $11.00 \mathrm{~d}$ & $33.33 \mathrm{~cd}$ \\
\hline A 25 & $0.00 \mathrm{~d}$ & $66.67 \mathrm{abc}$ & $\begin{array}{l}\text { Fungisida } \\
\text { benomil }\end{array}$ & $0.00 \mathrm{~d}$ & $0.00 \mathrm{~d}$ \\
\hline
\end{tabular}

*Angka yang diikuti oleh huruf yang sama menunjukkan hasil tidak berbeda nyata 
Tabel 3 Tingkat hambatan relatif beberapa konsentrasi khamir terhadap perkembangan perkembangan Colletotrichum gloeosporioides pada buah avokad berdasarkan diameter bercak

\begin{tabular}{|c|c|c|c|c|c|}
\hline \multirow{2}{*}{$\begin{array}{l}\text { Isolat } \\
\text { khamir }\end{array}$} & \multicolumn{2}{|c|}{ Tingkat hambatan relatif* } & \multirow{2}{*}{$\begin{array}{l}\text { Isolat } \\
\text { khamir }\end{array}$} & \multicolumn{2}{|c|}{ Tingkat hambatan relatif } \\
\hline & $10^{6} \mathrm{~mL}^{-1}$ & $10^{7} \mathrm{~mL}^{-1}$ & & $10^{6} \mathrm{~mL}^{-1}$ & $10^{7} \mathrm{~mL}^{-1}$ \\
\hline A11 & $13.45 \mathrm{ef}$ & $14.29 \mathrm{defg}$ & A26 & $95.76 \mathrm{ab}$ & 48.29 bcde \\
\hline A12 & $21.36 \mathrm{~d}$ ef & $19.03 \mathrm{defg}$ & A27 & 49.80 bcde & $100.00 \mathrm{a}$ \\
\hline A13 & $5.32 \mathrm{ef}$ & $3.94 \mathrm{fg}$ & A28 & $66.67 \mathrm{abcd}$ & $94.20 \mathrm{a}$ \\
\hline A14 & $0.00 \mathrm{f}$ & $0.00 \mathrm{~g}$ & A31 & $73.07 \mathrm{ab}$ & 39.78 cdefg \\
\hline A 15 & $5.60 \mathrm{ef}$ & $8.82 \mathrm{efg}$ & A32 & $100.00 \mathrm{a}$ & $81.51 \mathrm{ab}$ \\
\hline A16 & 12.46 ef & $29.63 \mathrm{defg}$ & A33 & $100.00 \mathrm{a}$ & $81.51 \mathrm{ab}$ \\
\hline A17 & $9.24 \mathrm{ef}$ & $0.00 \mathrm{~g}$ & A34 & $92.75 \mathrm{ab}$ & $100.00 \mathrm{a}$ \\
\hline A21 & $24.28 \mathrm{cdef}$ & $14.78 \mathrm{defg}$ & A35 & $66.67 \mathrm{abcd}$ & $83.51 \mathrm{ab}$ \\
\hline A22 & $77.17 \mathrm{ab}$ & $51.35 \mathrm{bcd}$ & A36 & $69.40 \mathrm{abc}$ & $100.00 \mathrm{a}$ \\
\hline A23 & $83.47 \mathrm{ab}$ & 44.54 bcdef & A37 & $75.76 \mathrm{ab}$ & $100.00 \mathrm{a}$ \\
\hline A24 & 24.42 cdef & $94.41 \mathrm{a}$ & A38 & $95.83 \mathrm{ab}$ & $80.02 \mathrm{abc}$ \\
\hline A 25 & $100.00 \mathrm{a}$ & & $\begin{array}{l}\text { Fungisida } \\
\text { Benomil }\end{array}$ & $100.00 \mathrm{a}$ & $100.00 \mathrm{a}$ \\
\hline
\end{tabular}

*Angka yang diikuti oleh huruf yang sama menunjukan hasil tidak berbeda nyata

C. gloeosporioides di penyimpanan. Dari 8 isolat tersebut, hanya 4 isolat yang akan dikarakterisasi lanjut, yaitu isolat A32, A33, A34, dan A37.

Buah avokad yang tidak diberi perlakuan khamir tampak ditumbuhi oleh cendawan pascapanen dan menunjukkan gejala penyakit antraknosa pada 8 hari setelah inokulasi C. gloeosporioides. Buah avokad yang diberi perlakuan fungisida benomil tidak menunjukkan adanya gejala bercak pada titik inokulasi, demikian juga yang diberi perlakuan khamir A32, A33, A34, dan A37 (Gambar 1).

\section{Kemampuan Khamir untuk Menghambat} C. gloeosporioides dan Aktivitas Kitinolitiknya

Uji in vitro aktivitas antibiosis khamir terhadap C. gloeosporioides pada medium PDA menunjukkan tidak ada satu pun khamir yang memberi zona hambat. Demikian juga seluruh isolat khamir yang diisolasi dari buah avokad hingga hari ke-7 tidak menunjukkan zona bening pada medium agar-agar kitin.

\section{Identifikasi Khamir}

Amplifikasimenggunakan pasangan primer ITS1/ITS4 berhasil mendapatkan pita DNA target berukuran $\pm 500 \mathrm{pb}$ dari isolat khamir A32, A33, A34, dan A37 (Gambar 2). Hasil analisis BLAST menunjukkan tingkat kesamaan sikuen nukleotida dengan Wickerhamomyces anomalus (Pichia anomala) sebesar 99\% untuk isolat A33 dan A37, serta dengan Candida intermedia sebesar 100\% untuk isolat A35 dan A36.

\section{PEMBAHASAN}

Salah satu faktor penentu daya saing produk dalam perdagangan bebas ialah jaminan mutu dan keamanan pangan bagi konsumen dalam menggunakan produk tersebut. Perhatian masyarakat terhadap peningkatan kesehatan dan lingkungan mendorong pengembangan metode pengendalian penyakit yang lebih ramah lingkungan dan aman bagi manusia (Droby 2006). Kementerian Kesehatan dan Kementerian Pertanian Republik Indonesia menetapkan batas minimal residu produk pertanian khususnya benomil pada avokad sebesar $0.5 \mathrm{mg} \mathrm{kg}^{-1}$ (Kementrian Pertanian 2008).

Agens pengendali hayati telah dilaporkan cukup efektif untuk mengendalikan penyakit pascapanen (Kefialewa dan Ayalewb 2009). Penggunaan mikrob, khususnya khamir, pada permukaan buah dan sayuran telah banyak dipilih untuk mengendalikan penyakit pascapanen. Khamir digunakan sebagai agens hayati pada penyakit pascapanen karena cepat 


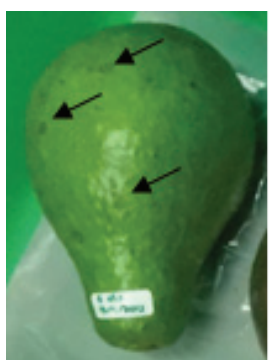

a

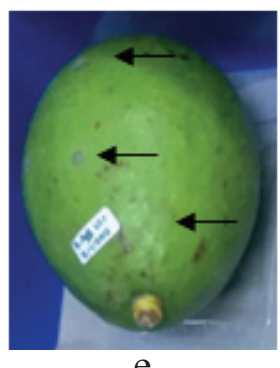

e

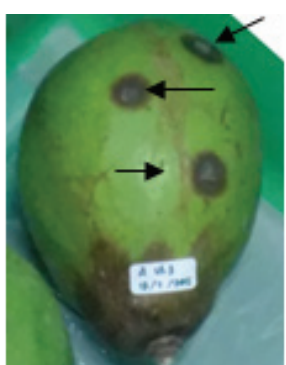

b

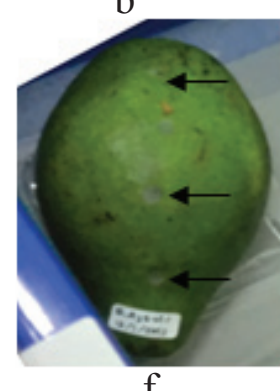

f

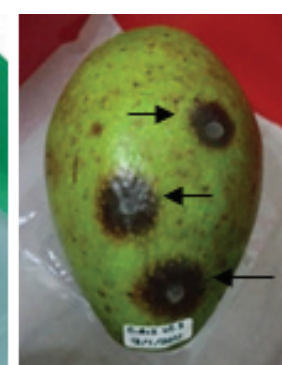

c

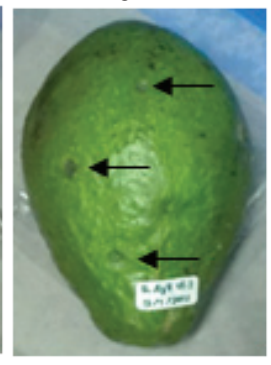

g

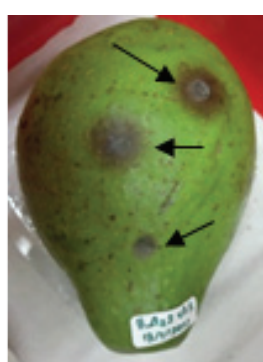

d

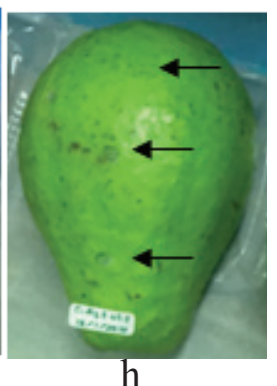

h

Gambar 1 Hasil inokulasi Colletotrichum gloeosporioides pada buah avokad pada 4 hari setelah inokulasi. a, perlakuan Benomil; b, tanpa perlakuan; c, perlakuan khamir isolat A12; $\mathrm{d}$, perlakuan khamir isolat A31; e, perlakuan khamir isolat A33; f, perlakuan khamir isolat A35; g, perlakuan khamir isolat A36; h, perlakuan khamir isolat A37. Tanda panah, lokasi yang ditetesi dengan C. gloeosporioides.

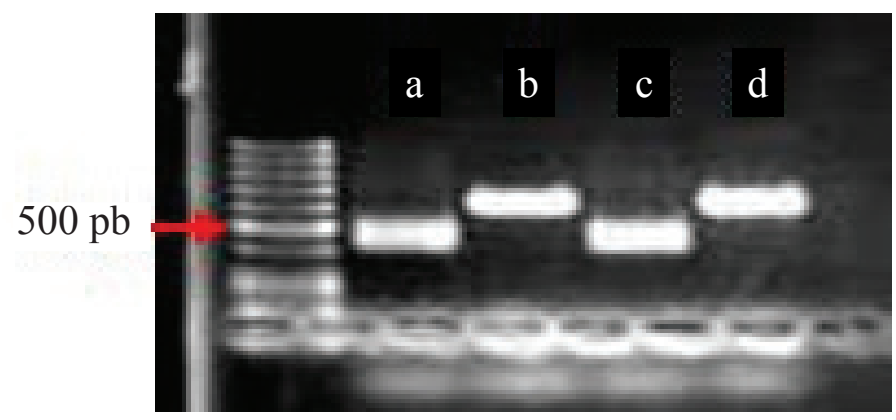

Gambar 2 Visualisasi DNA hasil amplifikasi isolat khamir menggunakan pasangan primer ITS1/ITS4. a, isolat A32; b, isolat A33; c, isolat A37; d, isolat A34.

mengolonisasi dan bertahan pada permukaan buah dalam waktu yang cukup lama pada berbagai kondisi, mampu berkompetisi dalam penggunaan nutrisi dengan patogen, kebutuhan nutrisi khamir sederhana, dapat tumbuh cepat dengan menghasilkan sel dalam jumlah besar, tidak menghasilkan spora alergik atau mikotoksin, serta menghasilkan vitamin, mineral, dan asam amino penting yang digunakan dalam makanan (Hashem dan Alamri 2009).

Hasil uji antibiosis secara in vitro dan kemampuan kitinolitik pada penelitian ini menunjukkan bahwa antibiosis dan produksi enzim kitinase bukan merupakan mekanisme kerja khamir dalam mengendalikan penyakit antraknosa pada buah avokad selama penyimpanan. Mekanisme penghambatan patogen oleh khamir melalui produksi kitinase telah dilaporkan oleh El Gaouth et al. (2003). Mekanisme penghambatan lainnya adalah dengan menghasilkan sekresi yang menghambat patogen (Guetsky et al. 2002), melekat pada dinding sel cendawan, aktivitas peroksidase (El Gaouth et al. 2003), kompetisi ruang dan nutrisi serta induksi ketahanan (Guetsky et al. 2002; El Gaouth et al. 2003).

Dua spesies khamir, yaitu Pichia anomala dan Candida intermedia berhasil diidentifikasi pada penelitian ini. $P$. anomala adalah 
khamir yang termasuk dalam kelompok Ascomycetes yang ditemukan secara alami berada pada makanan, biji-biji sereal dan memiliki kemampuan menghambat beberapa cendawan (Fredlund 2004). P. anomala juga diklasifikasikan sebagai organisme yang aman dan belum ada laporan yang menyatakan bahwa khamir ini menghasilkan mikotoksin yang berbahaya atau memproduksi spora penyebab alergi. Candida intermedia diketahui dapat menghambat pertumbuhan Colletotrichum graminicola dan C. sublineolum penyebab penyakit antraknosa pada sorgum dan jagung. Hasil uji antagonis $C$. intermedia yang diisolasi dari rizosfer tanaman tebu terhadap C. graminicola menunjukkan bahwa C. intermedia mampu menekan pertumbuhan cendawan patogen dengan memberikan reaksi antagonisme dari $45.9 \%$ sampai $48.9 \%$ sedangkan hasil uji antagonis $C$. intermedia terhadap $C$. sublineolum menunjukkan bahwa C. intermedia mampu menekan pertumbuhan cendawan patogen dengan memberikan reaksi antagonisme dari $47.7 \%$ sampai $48.9 \%$ (RosaMagri et al. 2011).

Beberapa isolat khamir yang diisolasi dari buah avokad terbukti potensial untuk digunakan sebagai agens biokontrol untuk penyakit antraknosa terutama pada buahbuah di tempat penyimpanan. Diperlukan serangkaian penelitian lanjut untuk mengetahui mekanisme kerja khamir dalam menghambat perkembangan C. gloeosporioides, penyebab penyakit antraknosa pada buah avocad.

\section{DAFTAR PUSTAKA}

Droby S. 2006. Biological control of postharvest disease of fruit and vegetables: difficulties and challenges. Phytopathol Pol. 39:105-117.

Fredlund E. 2004. Central carbon metabolism in the biocontrol yeast Pichia anomala: influence of oxygen limitation [disertasi]. Uppsala (IN): Swedish University of Agricultural Sciences.
El Ghaouth A, Wilson CL, Wisniewski M. 2003. Control of postharvest decay of apple fruit with Candida saitoana and induction of defense responses. Phytopathology. 93:344-348. DOI: http://dx.doi.org/10. 1094/PHYTO.2003.93.3.344.

Guetsky R, Shtienberg D, Elad Y, Fischer E, Dinoor A. 2002. Improving biological control by combining biocontrol agents each with several mechanisms of disease suppression. Phytopathology. 92:976-985. DOI: http://dx.doi.org/10.1094/PHYTO. 2002.92.9.976.

Hashem M, Alamri S. 2009. The biocontrol of postharvest disease (Botryodiplodia theobromae) of guava (Psidium guajava L.) by the application of yeast strains. Postharvest Biol Technol. 53:123130. DOI: http://dx.doi.org/10.1016/j. postharvbio.2009.04.001.

Kefialewa Y, Ayalewb A. 2009. Postharvest biological control of anthracnose (Colletotrichum gloeosporioides) on mango (Mangifera indica). Postharvest Biol Technol. 50:8-11. DOI: http://dx.doi. org/10.1016/j.postharvbio.2008.03.007.

Kementerian Pertanian. 2008. Peraturan Menteri Pertanian Nomor 35/Permentan/ OT.140/7/2008 tentang Persyaratan dan Penerapan Cara Pengolahan Hasil Pertanian Asal Tumbuhan yang Baik (Good Manufacturing Practices). Jakarta (ID): Mentan.

Robiglio A, Sosa MC, Lutz MC, Lopes CA, Sangorr'n MP. 2011. Yeast biocontrol of fungal spoilage of pears stored at low temperature. Int $\mathrm{J}$ Food Microbiol. 147(3):211-216. DOI. http://dx.doi.org/ 10.1016/j.ijfoodmicro.2011.04.007.

Rosa-Magri MM, Tauk-Tornisielo SM, Ceccato-Antonini SR. 2011. Bioprospection of yeast as biocontrol agent against phytopathogenic molds. Braz Arch Biol Technol. 54(1):1-5. DOI: http://dx.doi. org/10.1590/S1516-89132011000100001. 